\title{
A JUSTIFICATIVA DA PEDAGOGIA DO OPRIMIDO 50 ANOS DEPOIS: ELEMENTOS PARA UMA NECESSÁRIA REFLEXÃO ONTOLÓGICA
}

Diego Chabalgoity ${ }^{\mathrm{i}}$

\begin{abstract}
Resumo: Este artigo tem como objetivo trazer contribuições para uma reflexão ontológica necessária aos educadores populares de nosso tempo. Trata de uma reflexão acerca da "Justificativa da Pedagogia do oprimido" que não somente dá nome ao primeiro capítulo do livro, mas influencia todo o texto. Utilizando matrizes marxistas e decoloniais, são abordados os seguintes pontos: o contexto em que se insere a Pedagogia do oprimido, determinante para seu caráter decolonial e marxista; o conceito de "duração" da dialeticidade permanência-mudança, fundamentação necessária à discussão ontológica proposta; e à guisa de conclusão, uma breve reflexão sobre a atualidade da justificativa da Pedagogia do oprimido, que se mostra como obra indispensável à formação da identidade do educador popular.
\end{abstract}

Palavras chave: Ontologia do oprimido. Descolonialidade. Marxismo.

\section{LA JUSTIFICATIVA DE LA PEDAGOGÍA DEL OPRIMIDO 50 AÑOS DESPUÉS: ELEMENTOS PARA UNA NECESARIA REFLEXIÓN ONTOLÓGICA}

Resumen: Este artículo tiene como objetivo traer contribuciones para una reflexión ontológica necesaria a los educadores populares de nuestro tiempo. Trata de la "Justificación de la Pedagogía del oprimido", que no solo intitula el primer capítulo, sino que está presente en toda la obra. Utilizando matrices marxistas y decoloniales, se abordan los siguientes puntos: el contexto en que se inserta la Pedagogía del oprimido, determinante para su carácter decolonial y marxista; el concepto de "duración" de la dialéctica permanencia-cambio, fundamentación necesaria para la discusión ontológica propuesta; y a la luz de conclusión, una breve reflexión sobre la actualidad de la justificación de la Pedagogía del oprimido, que se muestra como obra indispensable para la formación de la identidad del educador popular.

Palavras clave: ontología del oprimido; decolonialidad; marxismo.

\section{Introdução}

Este artigo, escrito em celebração aos 50 anos da Pedagogia do oprimido, tem como objetivo trazer contribuições para uma reflexão ontológica necessária aos educadores populares de nosso tempo.

Para tanto, será realizada uma reflexão acerca da "Justificativa da Pedagogia do oprimido" que não somente dá nome ao primeiro capítulo do livro, mas influencia todo o texto. Focando a obra de Freire através de matrizes marxistas e decoloniais, o presente trabalho busca demonstrar a atualidade do mais famoso livro da educação brasileira.

Os seguintes pontos serão abordados: o contexto em que se insere a redação da Pedagogia do oprimido, determinante para seu caráter decolonial e marxista; o conceito de 
"duração" da dialeticidade permanência-mudança, fundamentação necessária à discussão ontológica proposta; e à guisa de conclusão, uma breve reflexão sobre a atualidade da justificativa da Pedagogia do oprimido, que se mostra como obra indispensável à formação da identidade do educador popular e, a uma maior compreensão do próprio povo brasileiro.

\section{Algumas considerações em torno do contexto da pedagogia do oprimido}

Foi no Chile, país em que Freire viveu exilado entre 1964 e 1969, que foi escrita a Pedagogia do Oprimido. Para compreensão da obra que em 2018 completa 50 anos, é fundamental que se analise o contexto em que o autor estava inserido, implicado decisivamente na conjuntura política de América Latina à época. A Guerra Fria encontra seu auge nesse período, especialmente em nosso continente, em que eclodem diversos golpes de estado, todos com a participação direta dos Estados Unidos da América.

Esses golpes não acontecem desvencilhados do bloco histórico referido; por isso mesmo, atestam a tensão entre os projetos capitalista e socialista. A força do triunfo cubano, de Guevara e a luta pela libertação de Nossa América do jugo colonial estavam presentes como um espectro por todo continente. A Pedagogia do oprimido está inserida nesse contexto. É proveitoso recordar que o livro é escrito entre 1966 e 1968, ou seja, menos de uma década depois da tomada de poder na famosa ilha caribenha.

Não à toa, é fato que o amadurecimento intelectual e político de Freire no período se deve ao seu exílio e ao contato com outros exilados, mas, principalmente, à possibilidade concreta de revolução. Anos mais tarde, relembrando o período, Freire revela a importância da vivência no Chile:

Acho que uma das coisas fundamentais que propunha era exatamente a questão política da educação, que foi ficando cada vez mais clara não apenas no discurso que eu fazia, a nível de interpretação das experiências junto aos quadros de educadores, mas sobretudo à medida que eles iam aplicando essas ideias. (FREIRE \& GUIMARÃES, 1987, p. 84).

Tal amadurecimento e a "radicalização crescente" (FREIRE \& GUIMARÃES, 1987, p. 12) de suas ideias devem, sobremaneira, à "efervescência latino-americana" (FREIRE, 1992, p. 22-23) vivenciada pelo autor nos primeiros anos de exílio. Freire pôde refinar e avaliar suas experiências no Brasil antes do golpe, fazendo uma crítica que o aproximaria definitivamente do pensamento dialético: 
A efervescência latino-americana, a presença cubana, hoje, tanto quanto antes, ameaçada pelas forças reacionárias que, cheias de si, falam da morte do socialismo, seu testemunho de que era possível mudar, as teorias guerrilheiras, a 'teoria do foco', a personalidade carismática extraordinária de Camilo Torres, em quem não havia dicotomia entre transcendentalidade e mundanidade, história e meta-história; a teologia da libertação, tão cedo provocando temores, tremores e raivas, a capacidade de amar de Guevara, sua afirmação tão sincera quanto marcante; 'Dejeme decirle', escreveu ele a Carlos Guijano, 'a riesgo de parecer ridículo, que el verdadero revolucionário es animado por fuertes sentimientos de amor. Es imposible pensar un revolucionario auténtico sin esta calidad'.

Maio de 68, os movimentos estudantis mundo afora, rebeldes, libertários; Marcuse, sua influência sobre a juventude. A China, Mao Tsé-Tung, a revolução cultural. (FREIRE, 1992, p. 22-23).

O contato que Freire trava com o marxismo nesse período é determinante ${ }^{\mathrm{ii}}$ para uma longa autocrítica que virá a ser realizada, assim como para a própria construção da Pedagogia do oprimido. A autocrítica se dará principalmente através da assunção dos elementos idealistas contidos nas experiências de alfabetização no Brasil, e, portanto, na Educação como prática da liberdade. Considerando criticamente as exepriências relatadas em seu primeiro livro, a dialética materialista ajudará Freire a rever o papel então atribuído à consciência na transformação da realidade, como se a tomada de consciência da condição de oprimido fosse a mola propulsora para o engajamento na transformação, ou até mesmo uma espécie de início da própria transformação. Posteriormente, Freire se refere a esse idealismo como “debilidade". (FREIRE, 2001, p. 154).

No que diz respeito à construção da Pedagogia do oprimido como um todo, a aproximação marxista o faz dar a devida importância para a imperativa necessidade de transformação das estruturas de opressão, e termina por reforçar e fundamentar o caráter ontológico de análise decolonial que deverá imprimir a partir de então.

Do ponto de vista marxista em que nos colocamos, a problematização é apresentada pelo próprio Freire, na Pedagogia do oprimido. Em suas Primeiras palavras o autor classifica sua postura como radical, oposta ao que chama de sectários. Significa dizer que o autor se coloca no campo metodológico do marxismo, mas com o cuidado de tornar explicita sua discordância com a leitura dos marxistas mecanicistas ou economicistas, para ele, antidialéticos.

Contudo, entendo que Freire não esgota tal celeuma circunscrevendo a contribuição marxista à percepção da necessária dialética entre a transformação das estruturas e das consciências. Não se trata somente da superação de uma perspectiva idealista em que a tomada de consciência é o carro-chefe do engajamento político e da transformação social; tampouco se trata apenas da correlata denúncia da oposta falsa crença estruturalista, em que a consciência é mero fruto mecanicista. 
A novidade é que Freire atrela essa dialética e o poder transformador das classes oprimidas - trazidos pela leitura de Marx- ao caráter decolonial que o vem acompanhando desde a influência do Instituto Superior de Estudos Brasileiros (ISEB), de leitura liberal, que agora, redirecionado pelo marxismo, pode definir seu verdadeiro sentido ontológico.

Nesse contexto, as influências de Frantz Fanon e Albert Memmi são, também, muito importantes para a época e estão vívidos no texto de Freire. Quanto ao primeiro, para além da epígrafe da Pedagogia do oprimido e sua famosa referência, não é demais citar que a primeira edição italiana do livro ora homenageado contém, na capa, os dizeres: "Do Terceiro Mundo, o livro mais importante desde Os Condenados da Terra". No que diz respeito à influência de Memmi, o diálogo com o livro do tunisiano, de 1957, nos mostra sua importância através de conceitos centrais no texto do brasileiro, como invasão cultural e a ideia da consciência dominadora hospedada no oprimido.

Já com bons anos de experiência e com sua bagagem "brasileira" de estudos sobre o existencialismo e a fenomenologia, no Chile Freire pôde reexaminar suas ideias, agora com um contato mais aprofundado com os autores decoloniais citados e com o marxismo.

Ressaltamos aqui, contudo, o foco na defesa de que a efervescência latino-americana, o exílio, a possibilidade concreta de revolução, a radicalização vivenciada, só poderiam ter lugar na América Latina. Mirada determinante para a Pedagogia do oprimido, Nossa América deve ser tomada como ponto de partida de qualquer análise marxista sobre esta obra de Paulo Freire, como veremos a seguir.

\section{Da justificativa da pedagogia do oprimido}

Em estudo sobre os primeiros e decisivos anos de construção do pensamento filosófico em Freire (CHABALGOITY, 2015), demonstramos que a síntese filosófica freiriana não trata simplesmente de uma miscelânea de diferentes escolas de pensamento, mas sim de uma tradução ${ }^{i i i}$ - nos termos da filosofia da práxis - que traz como lentes decisivas a perspectiva ontológica do oprimido.

Se nos propomos uma análise marxista da obra freiriana, é muito importante que se considere que a enorme contribuição do autor ao marxismo e à fundamentação do educador popular em América Latina, reside em grande parte no prisma decolonial que Freire opera do ideário marxista, denotando o papel da subjetividade na transformação da realidade e o caráter revolucionário de defesa da reflexão ontológica como ponto de partida. 
Neste sentido, é imperativo preliminar que se compreenda a amplitude do termo oprimido e as diferenças ontológicas para o ser genérico da tradição filosófica eurocêntrica, mesmo em se tratando do ser-para-o-outro da classe trabalhadora.

O conceito de oprimido, mesmo tendo sido usado por Marx e Engels, amplia sobremaneira a ideia de classe social trabalhadora (proletariado) como entendida pelos pensadores alemães. Isso porque a compreensão dos esfarrapados da Terra demanda uma leitura da constituição histórica do povo latino-americano.

Essa ideia não renega a luta de classes, senão que a fortalece como motor da história. A reflexão ontológica está presente desde a origem do método materialista-dialético. A análise freiriana se mostra muito atenta a isso, como vemos no comentário contido na Pedagogia da Esperança:

Na primeira vez, (...) em que li uma dessas críticas, me impus algumas horas de releitura
do livro, contando às vezes em que, no texto todo, falava em classes sociais. Ultrapassei
duas dezenas. Não raro, numa só página, falo duas, três vezes de classes sociais. Só que
falei de classes sociais não como quem usava um clichê ou como quem se punha
temeroso de um possível inspetor ou censor ideológico que me espreitasse e a quem
devesse prestar contas. Os autores ou autoras de tais críticas, de modo geral, mesmo que
nem sempre explicitassem, se incomodavam centralmente com alguns pontos. A já
referida vaguidade do conceito de oprimido como do de povo, a afirmação que faço no
livro de que o oprimido, libertando-se, liberta ao opressor, o não haver, como antes
sublinhei, declarado que a luta de classes é o motor da história, o tratamento que eu o
[sic] indivíduo, sem aceitar reduzi-lo a puro reflexo das estruturas socioeconômicas, o
tratamento que dava à consciência, à importância da subjetividade; o papel da
conscientização que, na Pedagogia do oprimido, supera, em termos de criticidade, o papel
a ela atribuído em Educação como prática da liberdade; a asserção de que "a aderência"
à realidade em que se encontram as grandes massas camponesas da América Latina está a
exigir que a consciência de classe oprimida passe, senão antes, pelo menos
concomitantemente pela consciência de homem oprimido. (FREIRE, 1992, p. 46).

Esse tratamento de criticidade, coerente ao cuidado com as leituras passivas, também é dispensado à Albert Memmi, que nos diz:

A colonização é primeiramente uma exploração político-econômica". Acrescentei, porém, que é de uma relação povo a povo e não classe a classe, que se trata. É isso que constitui, a meu ver, o aspecto específico da opressão colonial. (MEMMI, 2007, p. 17).

A visão de Freire é mais enfática do que a perspectiva de Memmi na medida em que, para o autor nordestino, a opressão colonial não trata de simples opressão povo a povo. Sua leitura marxista não lhe deixa esquecer a luta de classes que se dá dentro dos próprios países.

De todo modo, considerando as duas citações, o que nos importa aqui defender é que, do ponto de vista da tradutibilidade freiriana, uma revolução socialista em América Latina não poderia estar desvencilhada da libertação do jugo colonial, este é o sentido para onde aponta sua reflexão ontológica. 
Semeraro (2009) realiza estudo de grande valia para a discussão, uma vez que elucida as diferenças entre o oprimido e o subalterno. Àquele, além de suas posses materiais, lhe foi negado o direito à própria condição de sujeito histórico, submetido à conquista e à colonização:

Diferentemente do trabalhador europeu (...) o que se descobre na América Latina é um ser humano ao qual se nega a história. (...) O "oprimido" - como analisa E. Dussel- é o "sujeito negado", o sujeitado, a "vítima que não pode viver”. (SEMERARO, 2009, p. 26).

Diferentemente dos "subalternos" concebidos na história capitalista dos países europeus e de seus movimentos de trabalhadores, aos quais lhe roubaram, grosso modo, seu capital; ao oprimido lhe usurparam, sobretudo, o direito de dizer e criar sua própria história. Foi não somente subjugado, mas posto em uma condição de inferioridade, naturalizado em ser dominado através do colonialismo capitalista.

Somente após estas considerações ontológicas iniciais podemos nos debruçar sobre a justificativa da Pedagogia do oprimido.

É imprescindível considerar que todo o primeiro capítulo do livro trata diretamente de uma reflexão neste sentido que servirá de fundo para sua construção teórica e ético-política:

\begin{abstract}
Mais uma vez os homens, desafiados pela dramaticidade da hora atual, se propõem, a si mesmos, como problema. Descobrem que pouco sabem de si, de seu "posto no cosmos", e se inquietam por saber mais. Estará, aliás, no reconhecimento do seu pouco saber de si uma das razões desta procura. Ao instalar-se na quase, senão trágica descoberta do seu pouco saber de si, se fazem problema a eles mesmos. Indagam. Respondem, e suas respostas os levam a novas perguntas.

O problema de sua humanização, apesar de sempre dever haver sido, de um ponto de vista axiológico, o seu problema central, assume, hoje, caráter de preocupação iniludível. (FREIRE, 2005, p. 31).
\end{abstract}

Se propor a si mesmo como problema, trata, evidentemente, de uma reflexão ontológica. Como já foi colocado acima, o oprimido é uma categoria diferente do subalterno europeu, concebido na luta de classes europeia: se desse lhe roubaram os modos de produção, o capital; daquele, além de ter sido usurpado de seus modos seculares de produção, foi impedido de dizer e criar sua própria história, impedido de ser, posto em condição ontológica de inferioridade, dessa forma naturalizado nas relações (de)formadoras de colonização. A luta de classes na América Latina, como nos leva a crer Freire sem olvidar de sua base econômica e material de opressão, trata da luta por realizar-se ontologicamente, de deixar de ser-para-outro. Essa luta passa, em um só movimento dialético, pela identidade latinoamericana e pela luta contra o capitalismo como raiz da opressão. 
O caráter iniludível da desumanização, a que Freire se refere, não se mostra apenas em algo que está "escancarado" aos olhos de todos, como a miséria, a desnutrição, etc. Além de quaisquer dimensões formais, sob a perspectiva do oprimido, o caráter "iniludível" da desumanização o impele na luta por saber mais de si e das relações de opressão que determinam sua existência como ser-para-outro. A pedagogia do oprimido revela um prisma decolonial que implica a leitura mais crítica da sociedade e de sua dinâmica.

O que torna iniludível para Freire a busca necessária pela vida, pela humanização. Em que se busque um sentido mais antropológico que antropocêntrico para a humanidade, uma educação que tenha como intencionalidade a formação humana, a humanização e não a formação humanitarista, orgânica ao modo de produção capitalista.

O contato com o marxismo leva Freire a perceber definitivamente que a educação não transforma a realidade, mas deve, junto com ela, se transformar. Se a ideia de formação humana está intimamente ligada ao trabalho como princípio educativo, Freire a amplificará compreendendo o movimento popular todo ele como princípio educativo.

É justamente a percepção das dinâmicas da sociedade de classes - possível somente após o contato com as leituras marxistas-, em que o projeto das classes dominantes será também o projeto dominante de educação, que Freire compreende a necessidade de uma nova metodologia que dê suporte à práxis das classes dominadas. A metodologia das classes dominantes só serve aos interesses das classes dominantes. Ao captar o significado profundo disto, Freire enlaça de forma dialética e radical a educação para a transformação das estruturas à significação ontológica dos porquês da necessária transformação das estruturas de opressão.

Se o mundo material é limitado, a consciência também será. Não há lugar aqui para escolanovismos que reneguem o contato com o patrimônio cultural da humanidade como condição sine qua non para o entendimento crítico das relações de opressão; mas também não se pode cair em uma espécie de "idealismo espelhado", em que não se pense como ponto de partida metodológico a imanência do oprimido. Anos mais tarde, Freire fundamentará que não se pode fazer educação popular, no sentido da elevação cultural, sem a participação consciente das camadas populares nesse processo.

Essa metodologia nos mostra que não é possível pensar qualquer princípio educativo desvencilhado da criação prática do mundo. Se o trabalho é construção do gênero humano por ele mesmo, o princípio educativo só se fará perceber na apropriação do novo para sua autocriação. 
O princípio educativo se realiza no mundo concreto e não no mundo das ideias. A realidade do oprimido deve ser transformada para que ele possa vir-a-ser. Essa é a grande ideia que fundamenta a justificativa da pedagogia do oprimido:

Se admitíssemos que a desumanização é vocação histórica (...) a luta pela humanização, pelo trabalho livre, pela desalienação, pela afirmação dos homens como pessoas, como "seres para si”, não teria significação. Esta somente é possível porque a desumanização, mesmo que um fato concreto na história, não é porém, destino dado, mas resultado de uma "ordem" injusta que gera a violência dos opressores e esta, o ser menos. (FREIRE, 2005, p. 32).

\section{A “duração" da dialeticidade permanência-mudança}

Nas últimas páginas da Pedagogia do oprimido, Freire nos deixa uma questão que será elaborada em toda sua obra. É de grande valia para a discussão a que nos propomos. Trata-se da “duração" da dialeticidade permanência-mudança:

$\mathrm{Na}$ verdade, o que faz que a estrutura seja estrutura social, portanto histórico-cultural, não é a permanência nem a mudança, tomadas absolutizadas, mas a dialetização de ambas. Em última análise, o que permanece na estrutura social nem é a permanência nem a mudança mas a "duração" da dialeticidade permanência-mudança. (FREIRE, 2005, p. 207).

São conhecidos os ensinamentos de Freire de que toda prática educativa trata de uma opção cultural que incide na estrutura social, seja na sua permanência, seja na sua mudança. A grande contribuição de Freire, do ponto de vista ontológico, está em demonstrar que essa opção não trata de uma opção puramente metodológica, mas antes disso, uma opção de intencionalidade, uma opção ético-política.

A viabilidade ontológica de humanização é entendida por Freire como iniludivel, na medida em que a própria vocação histórica dos seres humanos se sustenta nessa reflexão: a certeza de que "a estrutura social, para ser, tenha que estar sendo" (Freire, 2005, p. 207).

A ontologia humana é entendida como um fato, como imanência. A ontologia do oprimido (CHABALGOITY, 2015) se torna assim, igualmente, um fato. A intencionalidade da pedagogia do oprimido encontra sentido ético-político na certeza de que se trata de transformar a realidade concreta, transformar as relações de opressão. Há uma dialética indivisível entre a metodologia então em construção pelo autor e a própria significação da intencionalidade educativa.

No que diz respeito ao sentido ético-político do pensamento decolonial, encontramos no Freire maduro um relato explícito de como o autor compreende as relações entre a duração da 
dialeticidade referida e o jugo colonial de Nossa América. O autor versa no texto crítico aos 500 anos da conquista pelos colonizadores, sobre a ideia de passado:

\begin{abstract}
Certamente o passado jamais passa no sentido que o senso comum entende por passar. A questão fundamental não está em que o passado passe ou não passe, mas na maneira crítica, desperta, com que entendamos a presença do passado em procedimentos do presente. Nesse sentido, o estudo do passado traz à memória de nosso corpo consciente a razão de ser de muitos dos procedimentos do presente e nos pode ajudar, a partir da compreensão do passado, a superar marcas suas. A compreender, no caso, por exemplo, do passado da conquista como, sem dúvida, ela se repete hoje, de forma diferente, às vezes. É exatamente porque o passado se faz presente, seja o passado do conquistador, seja o do conquistado, que os quilombos, momento exemplar da luta dos conquistados, se repetem hoje nas lutas populares no chão da América. A conquista atual, que prescinde do corpo físico do conquistador, se dá pela dominação econômica, pela invasão cultural, pela dominação de classe, através de um sem-número de recursos e instrumentos de que os poderosos, neo-imperialistas, se utilizam. Entre eles, os instrumentos assistencialistas, os empréstimos de que resulta o endividamento crescente dos submetidos. Para isso tudo, os poderosos de hoje, como os de ontem, contam com algo de importância fundamental: a conivência dos dominados, enquanto seres duais. Por isso mesmo têm também de enfrentar o gosto de liberdade dos oprimidos, dos invadidos, dos deserdados, com que estes, despertos, de pé, às vezes na sombra, taticamente silenciosos, "azucrinam" a cabeça dos poderosos. E é exatamente esta vontade de ser nós mesmos e este desejo forte, alentados pelo sonho possível, pela UTOPIA ${ }^{\text {iv }}$ tão necessária quanto viável, que marchamos os progressistas e as progressistas destas Terras de América para a concretude, a realização dos sonhos dos Vascos, de Quiroga y Tupac, dos Bolívares, dos San Martins, dos Sandinos, dos Tiradentes, dos Ches, dos Romeros.

O futuro é dos Povos e não dos Impérios. (FREIRE, 2000, p. 34-35).
\end{abstract}

Esta passagem, ainda que distante 25 anos da Pedagogia do oprimido, é relevante por atestar o espaço sempre destinado por Freire a esse tema. A atualidade da justificativa se revela mais atual do que nunca, sem risco de recairmos em tautologia. Isso porque ainda se trata da construção de uma pedagogia intencionada na formação humana.

Há de se buscar uma revolução em nossa velha sociedade colonial. As experiências reformistas dos governos Lula e Dilma comprovam que não basta a melhoria das condições imediatas das camadas populares. A parca transformação econômica que sofreu o Brasil nas últimas duas décadas não foi acompanhada de um projeto de educação que completasse essa dialética- que, de toda forma, não seria possível dentro da lógica capitalista.

Não nos surpreende que quem consegue realizar algo neste sentido no Brasil são os movimentos populares, cujo exemplo mais emblemático é o Movimento dos trabalhadores rurais sem terra (MST). Pois se trata justamente de uma educação em que a apropriação do conhecimento pelas consciências não se desvencilha da luta do movimento. A formação humana se dá dialeticamente com a formação da identidade do próprio movimento e de suas conquistas:

Afirmo, então, que este processo também pode ser interpretado como um processo de formação humana, e mesmo como a materialização de um determinado modo de produção da formação humana, cuja matriz é o próprio Movimento como sujeito e 
princípio educativo. Isto porque se fazemos o esforço de buscar compreender o sentido mais profundo da experiência humana de ser Sem Terra, ou ser do MST, nos encontramos com um movimento pedagógico de formação de sujeitos sociais e de seres humanos, que nos remete às questões de origem da própria reflexão pedagógica, ou da reflexão da educação como formação humana: como nos humanizamos, ou nos formamos como humanos? Como se educa uma pessoa para que se desenvolva em sua condição humana? Quais os valores que movem nossa intencionalidade educativa? Para que postura diante da sociedade nossa prática tem educado? (CALDART, 2000, p. 130-131).

Este relato de Caldart nos mostra que uma metodologia coerente com o ideário marxista, mesmo que partindo organicamente de um movimento com uma causa específica, ao fundamentar sua ontologia não vê saída a não ser na amplificação, para toda a sociedade, de seu ideário ético-político, que se forja na denúncia e se fortalece no anúncio. Isso está em direta relação com a justificativa do oprimido e é imperativo que o tenhamos em vista. Não à toa que, em entrevista à imprensa argentina, em 1996, poucos meses antes de morrer, Freire profetizou: “(...) dirão: o velho Paulo Freire tinha razão: a luta pelo homem e pela mulher buscando o seu próprio ser, seu desenvolvimento pleno, vai seguir acompanhando-nos." (FREIRE, 2008, p. 48). Para mais adiante arrematar:

Minha pedagogia segue sendo uma pedagogia da "gentificação", da "gentitude". Está voltada a formar boas pessoas e não somente especialistas. Esta é a posição que devemos assumir para frear e derrotar o avanço da ideológica do neoliberalismo. (FREIRE, 2008, p. 50).

\section{Para refletir: a atualidade da justificativa da pedagogia do oprimido - sua "duração" e a relevância do pensamento decolonial freiriano}

Na conjuntura ainda recente do Golpe que vivemos, a questão colonial no Brasil toma uma forma quase didática e se afigura como ilustração perfeita da mentalidade colonizada que insiste em (de)formar a identidade da classe média brasileira. Como era de se esperar, pouco tem se falado sobre isso.

Do ponto de vista dos fundadores da filosofia da práxis, o próprio conceito de classe média- para eles, os pequeno-burgueses- é questionável, uma vez que Engels, em nota ao título do primeiro capítulo do Manifesto Comunista deixa claro:

Por burguesia entende-se a classe dos capitalistas modernos, proprietários dos meios de produção social que empregam o trabalho assalariado. Por proletariado, a classe dos assalariados modernos que, não tendo os meios próprios de produção, são obrigados a vender sua força de trabalho para sobreviver. (MARX \& ENGELS, 2005, p. 40). 
A preocupação de Engels, a ponto de esclarecer na edição inglesa de 1888, quarenta anos depois do original, é categórica: se não detém os meios de produção, é classe trabalhadora. Pode até receber um ordenado de R \$ 10.000,00 por mês, ter acesso privilegiado ao arcabouço cultural da sociedade, poder ter as benesses de um trabalho intelectual, mas é, ainda assim, classe trabalhadora, uma vez que não detém os meios de produção.

Essa conceituação pode ser questionada e carregar robusta celeuma. Pode até não ser consensual. No entanto, quando operamos a tradutibilidade ${ }^{v}$ para nossas terras do Sul, e pensamos a mentalidade colonial sob um prisma marxista, a conceituação de Engels se torna mais iniludivel ainda.

A tradução decolonial de Freire revela a potência que o pensamento marxista carrega ao amplificar sobremaneira a fundamentação de nosso autor. Sem ter como foco iniludível a transformação das estruturas de opressão não seria possível a construção de tal ideário. Nesse sentido reverberamos Semeraro que, ao citar Marx, reitera a indivisível dinâmica entre opressão colonialista e opressão capitalista:

\begin{abstract}
Embora, de fato, se continue a ocultar o vínculo profundo entre a formação da modernidade capitalista e colonialismo, repetindo a ideia sem fundamento de uma Europa moderna "ascética" e autogerada das suas inerentes qualidade superiores, o tempo e os fatos provam cada vez mais que a concentração de poder nos países dominantes tem se formado em grande parte pela implantação do sistema colonial fundado sobre a exploração das "duas fontes de onde jorra toda riqueza: a terra e o trabalhador". (SEMERARO, 2009, p. 19-20).
\end{abstract}

O golpe de 2016 mostrou uma classe média brasileira incapaz de pensar com o próprio cérebro $^{\mathrm{vi}}$, facilmente manipulável. Existe nela flagrante homogeneidade e não carrega consigo um projeto de nação, não se realiza enquanto classe-para-si, uma vez que representa os interesses da elite como se fossem os seus. Pessoas que obtiveram acesso às melhores escolas, às melhores universidades, ao contato quase ilimitado à cultura- tanto erudita quanto popular, pasmem!foram enganadas, feitas de tolos. Duas explicações têm sido recorrentes: o ódio de classe e o analfabetismo político. Os dois fatores citados remetem à mentalidade colonial.

A questão colonial no Brasil tem figurado na academia de longa data e não é novidade. Podemos citar os estudos de Gilberto Freyre (1957), Raymundo Faoro (1984), Darcy Ribeiro (1995), Sérgio Buarque (2001) e Guerreiro Ramos (1993). Aqui, de forma breve, nos valemos do recente e crítico trabalho de Jessé Souza (2017).

Esse autor analisa nossos tempos atuais, permeados pelo golpe. No momento que escrevo passamos pelo nono dia de paralisação dos caminhoneiros. Os "camisas amarelas"- como se refere Souza, ainda em 2017- nada fazem: 
Se não fosse essa a razão, o que faria os "camisas amarelas" - versão nacional dos "camisa negra" de Mussolini - ficarem em casa quietinhos, agora, em meados de 2017, quando a corrupção real mostra sua pior face? Se fosse a corrupção o que indignasse esse povo, o panelaço deveria ser ensurdecedor agora, não concorda, leitor? Onde estão os “camisas amarelas"? É a seletividade da corrupção não só apenas no Estado, mas apenas dos partidos de esquerda, que querem diminuir a distância entre as classes sociais, o que verdadeiramente move e comove nossos "camisas amarelas". Deltan Dallagnol é sua mais perfeita expressão: líder tosco, primitivo, cheio de certezas e verdades seletivas. (SOUZA, 2017, p. 95).

O livro de Souza é relevante para nossa discussão, uma vez que denuncia o culturalismo racista inaugurado por Buarque (2001), que coloca o patrimonialismo e a concepção de brasileiro cordial como marcas indeléveis da formação do povo brasileiro, que as teria recebido como herança maldita irrefreável. Sem nenhum tipo de análise sobre o modo de produção capitalista, Buarque termina por sustentar a formação de um estado concebido de forma abstrata, sem nenhuma relação com a corrupção, esta, circunscrita à tal herança maldita.

Como sustenta Jessé Souza, o trabalho de Buarque, por ser de fôlego intelectual inquestionável, e pretender-se totalizador da sociedade brasileira, termina por legitimar uma leitura liberal e instransponível do povo brasileiro, do tipo "não há o que fazer". Apesar de grande, a citação é válida para nossa discussão:

Sérgio Buarque é o pai do liberalismo conservador brasileiro ao construir as duas noções mais importantes para a autocompreensão da sociedade brasileira moderna: a noção de homem cordial e a noção de patrimonialismo. O homem cordial é a concepção do brasileiro como vira-lata, ou seja, como conjunto de negatividades: emotivo, primitivo, personalista e, portanto, essencialmente desonesto e corrupto. O homem cordial deve ser tornado pelo mercado e pela industrialização um homem tão democrático, produtivo, puro e honesto como os americanos, o exemplo de homem-divino para Sérgio Buarque e para a esmagadora maioria dos brasileiros, intelectuais ou não. (...)

Já o patrimonialismo é uma espécie de amálgama institucional do homem cordial, desenvolvendo todas as suas virtualidades negativas dessa vez no Estado. Por alguma razão, Sérgio Buarque não constrói o mercado como marcado pela mesma viralatice. Aliás, o mercado sequer existe como configuração de interesses organizados, sendo a única instância institucionalizada e organizada, percebida pelo autor e apartada dos indivíduos, o próprio Estado. Além dele só existem indivíduos privados, sem que uma lógica da propriedade privada e sua tendência à acumulação ampliada, levando a oligopólios e monopólios, seja sequer mencionada. A lógica de funcionamento do mercado é tornada invisível e a noção de elite dominante, portanto, restringe-se à esfera estatal. (...)

A sacada genial de Sérgio Buarque de construir uma visão de mundo liberal conservadora - posto que esconde as verdadeiras razões da desigualdade e da injustiça social - com a aparência e o charme de uma suposta crítica social é a ideia-força mais importante para a compreensão da manutenção da desigualdade e da injustiça social no Brasil. Afinal, a injustiça flagrante dos privilégios que se tornam permanentes tem que ser - no contexto de uma sociedade que diz ter acabado com todos os privilégios de nascimento legitimada para que possa se reproduzir. (SOUZA, 2017, p. 108)

Souza defende que essa estrutura social brasileira encontra seu braço de intelectualidade orgânica de formação racista que ocorre em nossas universidades. Essa roupagem crítica a que se 
refere não é suficiente para esconder, contudo, o caráter legitimador desse tipo de abordagem sobre a mentalidade colonial, grupo em que se encontram Faoro, Freyre e Buarque.

Aqui voltamos a Paulo Freire. É importante colocar o autor em campo ideológico oposto no que diz respeito à formação colonial do Brasil. Para além da apropriação da leitura marxista que, por si só, já o colocaria em um nível mais crítico de entendimento, sua abordagem não é uma análise da formação colonial no país, mas sim um engajamento decolonial.

Apesar de pouco estudo nesse sentido no Brasil, há consenso na América do Sul e na África de que Freire é uma referência fundamental e determinante. Lander, se propondo a esquematizar as fontes e principais referências do pensamento decolonial latinoamericano afirma que "as contribuições principais a esta episteme latino-americana" (Lander, 2005, p. 9) residem na teologia da libertação, na filosofia da libertação de Enrique Dussel, e nas obras de Paulo Freire, Orlando Fals Borda e Alejandro Moreno. Em recente estudo de doutoramento, o educador moçambicano Orlando Daniel Chemane (2017) nos demonstra, em trabalho de fôlego, a imensurável presença de Paulo Freire na constituição do pensamento decolonial africano.

A despeito do reconhecimento internacional, Freire não é colocado, no Brasil, em pé de igualdade a esses autores, como uma referência para entender o povo brasileiro. De toda forma, a diferença de Freire para os autores liberais brasileiros citados é que sua análise não se tolhe em uma dialética abstrata que, sem esperança, recai sob uma resignação legitimadora do Brasil como um país de vira-latas- o que, como demonstra Jessé Souza, é o argumento ontológico central na manipulação da classe média.

A história, do ponto de vista decolonial freiriano, não trata somente de anunciar um futuro de liberdade, mas trata também da transformação do passado, da construção de uma outra narrativa. Uma nova perspectiva que se contraponha à narrativa dominante que, em sua atualidade na "duração" está sempre se reconstruindo para manter sua função orgânica de legitimação de uma sociedade de desigualdades e opressão.

Com esses elementos trazidos à tona, podemos constatar que tanto a justificativa, quanto na própria pedagogia do oprimido como um todo são extremamente atuais e relevantes.

Em primeiro lugar é de saltar aos olhos a atualidade da mensagem de que não se pode construir uma revolução socialista em Nossa América sem a denúncia do atrelamento de nascença entre as opressões capitalista e colonial- faces de uma mesma moeda. $\mathrm{O}$ caráter iniludível da desumanização trata da duração de uma dialeticidade em que tem saído vitoriosa a permanência das estruturas porque a dominação econômica se nutre da dominação cultural. Talvez para os brasileiros que vivem de costas para a América do Sul, isso fique distante de 
perceber, mas se ampliamos para a conjuntura do continente isso é facilmente perceptível ainda hoje.

Em segundo lugar, mas não menos importante porque em unidade dialética com o primeiro, é a inegociável presença das camadas populares nesse processo. Ou participam organicamente, ou recairemos eternamente em idealismos legitimadores de nossa sociedade de classes- o que poderíamos chamar, como Souza (2017), de patrimonialismo da esquerda.

A humanização no sentido ontológico proposto por Freire não trata da melhoria das condições de vida, de uma sensibilidade participativa e social, tampouco de um novo mundo melhorado, presente nas propostas reformistas; trata, de forma iniludível da criação de outro mundo, em que as classes oprimidas de América Latina possam, depois de séculos, vir-a-ser. A ontologia do oprimido (Chabalgoity, 2005) se realiza no mundo concreto e não no mundo das ideias.

\section{Referências bibliográficas}

BUARQUE, Sérgio. Raízes do Brasil. São Paulo: Companhia das Letras, 2001.

CALDART, R. O MST e a formação dos Sem Terra: o movimento social como princípio educativo. In: Gentili, P. \& Frigotto, G. (orgs.) A cidadania negada: políticas de exclusão na educação e no trabalho. Buenos Aires: CLACSO, 2000.

CHABALGOITY, D. Ontologia do oprimido: construção do pensamento fillosófico em Paulo Freire. Jundiaí: Paco Editorial, 2015.

CHEMANE, O. D. Paulo Freire, colonialismo, libertação e educação na África e Moçambique. Tese de doutoramento. Niterói: Universidade Federal Fluminente, 2017.

FAORO, R. Os donos do poder. Porto Alegre: Globo, 1984.

FREIRE, P. Pedagogia da esperança: um reencontro com a pedagogia do oprimido. Rio de janeiro: Paz e Terra, 1992.

Pedagogia da indignação: cartas pedagógicas e outros escritos. São Paulo:

UNESP, 2000.

. Ação cultural para a liberdade e outros escritos. $9^{\mathrm{a}}$ ed. Rio de janeiro: Paz e Terra, 2001.

Pedagogia do oprimido. $47^{\mathrm{a}}$ ed. Rio de Janeiro: Paz e Terra, 2005.

. Pedagogia do compromisso: América Latina e educação popular. Indaiatuba, SP:

Villa das letras, 2008. 
FREIRE, P. \& GUIMARÃES, S. Aprendendo com a própria história. Rio de Janeiro: Paz e Terra, 1987.

FREYRE, G. Casa-grande e senzala. Lisboa: Livros do Brasil, 1957.

GRAMSCI, A. Cadernos do cárcere: volume 1: introdução ao estudo da filosofia: a filosofia de Benedetto Croce. Rio de Janeiro: Civilização Brasileira, 2006.

GUERREIRO RAMOS, A. A redução sociológica. 3ª ed. Rio de Janeiro: UFRJ, 1996.

LANDER, E. Ciências sociais: saberes coloniais e eurocêntricos. In: LANDER, E. (org.) A colonialidade do saber: eurocentrismo e ciências sociais: Perspectivas latino-americanas Buenos Aires: CLACSO, 2005.

MEMMI, A. (1957) Retrato do colonizado precedido do retrato do colonizador. Rio de janeiro: Civilização brasileira, 2007.

RIBEIRO, D. O povo brasileiro: a formação e o sentido do Brasil. São Paulo: Companhia das letras, 1995.

SEMERARO, G. Libertação e hegemonia: realizar a América Latina pelos movimentos populares. Aparecida, SP: Ideias \& Letras, 2009.

SOUZA, J. A elite do atraso: da escravidão à Lava Jato. Rio de Janeiro: Leya, 2017.

\footnotetext{
i Professor Adjunto da Universidade Federal Fluminense - UFF no Departamento de Ciências Humanas do INFES UFF, em Santo Antônio de Pádua / RJ. É coordenador do Grupo de Estudos e Pesquisas sobre Paulo Freire e Educação Popular (GEPEP - UFF); e pesquisador do Núcleo de Estudos e Pesquisas em Filosofia, Política e Educação (NuFiPE - UFF)

${ }^{\text {ii }}$ Para estudo mais aprofundado, cf. Chabalgoity (2015); para depoimentos do próprio Freire, cf. $(1992 ; 2001)$ e Freire \& Guimarães (1987).

iii Utilizaremos no artigo, segundo terminologia gramsciana, o conceito de tradutibilidade. Na obra de Freire pode ser compreendido como a própria consubstanciação da filosofia da práxis, estando intimamente ligado à ideia de conscientização na Pedagogia do oprimido: “(...) o processo pelo qual (...) o sujeito se torna capaz de perceber, em termos críticos, a unidade dialética entre ele e o objeto. (...) não há conscientização fora da práxis, fora da unidade teórica-prática, reflexão-ação." (Freire, 2001, p. 163).

${ }^{\text {iv }}$ Grifo do autor.

${ }^{v}$ Gramsci. Cf., nota ii, acima.

${ }^{v i}$ Se trata de referência à Gramsci, no $§ 12$ do Caderno 11, que nos indaga: "É preferível 'pensar' sem disto ter consciência crítica, de uma maneira desregrada e ocasional, isto é, 'participar' de uma concepção de mundo 'imposta' mecanicamente pelo mundo exterior (...) ou é preferível elaborar a própria concepção de mundo de uma maneira consciente e crítica e, portanto, em ligação com este trabalho do próprio cérebro, escolher a própria esfera de atividade, participar ativamente na produção da história do mundo, ser o guia de si mesmo e não mais aceitar do exterior, passiva e servilmente, a marca da própria personalidade?" (Gramsci, 2006, p. 93-94).
} 